\title{
COMPARISON OF LEARNING METHOD EFFECTIVENESS BETWEEN JIGSAW AND TEAM GAME TOURNAMENT ON ACHIEVEMENT AND INTERPERSONAL RELATIONSHIP SKILL IN NURSING FRESHMEN
}

\author{
Made Indra Ayu Astarini..$^{*}$, Linda Juwita $^{2}$, Arif Helmi Setiawan. ${ }^{3}$ \\ ${ }^{1,2}$ Faculty of Nursing, Widya Mandala Catholic University Surabaya, Jl. Raya Kalisari \\ Selatan 1, Pakuwon City, Surabaya, Indonesia \\ ${ }^{3}$ Faculty of Nursing, Nahdlatul Ulama University, Jl. Raya Jemur Sari No.57, \\ Surabaya, Indonesia
}

\author{
Email*: madeayu@ukwms.ac.id
}

\begin{abstract}
Introduction: Evaluation results every semester about biochemical obtained by students the average value below 50. Cooperative learning method jigsaw and team game tournament (TGT) were an alternative learning method that can improved student learning outcomes. The purpose of this research was to understand the effectiveness of applied of jigsaw learning method compared to TGT to interpersonal relationship skill and achievement. Methods: This research used pre-experiment with research design Pretest-Posttest Comparison Group Design. Target population was all nursing students in two nursing institutions in Surabaya. Sample size were 208 chosen by total sampling. Independent variables were jigsaw and TGT and dependent variables were interpersonal relationship skill and achievement. Study instruments were interpersonal relationship skill questionnaire and objective test. Data analysis uses paired t test with $\alpha \leq 0.05$, prior normality test will be conducted. Results: Most respondents were 19 years old, single, female and lived with their parents. There was different result in student achievement between TGT and Jigsaw method ( $p=0,005)$, TGT mean rank was 97,89 than jigsaw was 76,52. There was no different interpersonal relationship ability between TGT and jigsaw method ( $p=0,263$ ). Conclusions: TGT more effective than jigsaw to increase student learning achievement in biochemical. Those method has not different for student interpersonal relationship ability, because the student has been in good criteria for interpersonal relationship ability. Further implementation could be broad, other object in nursing could be the target, difficult subject would be underlined.
\end{abstract}

Keyword: Jigsaw, team game tournament, interpersonal relationship skill, achievement

\section{INTRODUCTION}

Nursing is one of the health sciences that studies about human body. Biochemistry is one of the processes that occurs in the human body which includes methylism carbohydrates, protein and fat. According to Anwar et al (2014) understanding of biochemical concepts requires high-level thinking skills so that the approach needed is able to train these abilities. Based on student data obtained by researchers, nursing students still have low mastery of biochemistry subject, especially about the metabolism of carbohydrate, protein, and fat. This is apparent from the low grades of evaluation results each semester, with an average score of below 50. Based on an interview with students, they said that biochemistry subject is very difficult to understand.

Nursing Faculty still use a classic learning method for biochemistry subject in the form of a lecture. Students are not actively involved in finding and learning about the subjects. Such learning method will only develop the students' cognitive aspect, while affective aspects are also expected in the learning outcomes. The expected affective aspects expected is the ability in interpersonal relationships with classmates which can be achieved through group learning methods.

Educational institutions today are asked to carry out learning with a studentcentered approach. In this approach, students are the focus in the student learning process so that various cooperative 
learning methods emerge. Through cooperative learning, non-academic achievement can be achieved, such as interpersonal relationships and group collaboration (Alsa, 2010). One of the cooperative learning methods is the jigsaw method. According to Alsa (2010), the jigsaw method can improve an interpersonal relationship and cooperation skills in psychology students. Raksun (2008) stated that, the jigsaw method can improve students' learning achievement in basic biology subject and can also improve students' learning motivation.

The jigsaw method can be applied in a group with a heterogeneous ability. Each member is responsible for one part of the subjects being studied and will discuss each subject in the "expert group" and then they will return to share their knowledge in the original group. In addition to the jigsaw method, there are also other cooperative learning methods, the Team Game Tournament (TGT). TGT is a cooperative learning model that is easy to implement, involving all of the students' activities without any status difference, with students as peer tutors, and containing elements of game and reinforcement (Hamdani, 2011). According to Juwita (2017)), the TGT method can improve the learning outcomes and motivation of nursing students' in nervous system subjects. According to Veloo and Chairhany (2013), students can create an active learning atmosphere in terms of problem-solving and conducting discussion between students and teachers in the TGT method.

Jigsaw and TGT is a cooperative learning method which both effectively improves learning outcomes and social skills. Both methods divide students in a group which members have heterogeneous skills (Hariyanto, 2016). The difference between the two methods is that TGT method contains the elements of a game. Thus, it is necessary to know the difference between the effectiveness of both methods in improving the learning outcomes and the personal relationship skills of nursing students. The purpose of this study is to explain the difference in effectiveness between the jigsaw method compared to the
Team Game Tournament (TGT) methods on the learning outcomes and interpersonal relationship skills of nursing students in biochemistry subjects.

\section{METHODS}

\section{Study Design}

The study design was preexperimental with the Pretest-Posttest Comparison Group Design. The population in this study was all nursing students in Surabaya. The total population in April 2018 was 208 people. The sample size are 104 students each group. The sample in this study are from two nursing institution. Sample criteria consisted of: Inclusion criteria which were active students in the odd semester of 2018/2019 class. The exclusion criteria were those resigned during the study period and those did not attend all face-to-face meeting session in class. The independent variable in this study was the implementation of the jigsaw and Team Games Tournament (TGT) learning method. The dependent variables were learning outcomes and interpersonal relationship skills of students.

\section{Data Collection Methods and Study Instruments}

Data collection was done by first, the study team explained about the purpose and technical implementation of the study as well as the benefits that could be obtained by the respondents. Second, After the respondents understood and were willing to become a respondent, the study team distributed the agreement sheet for signed. Third, Researcher distributed the interpersonal relationship skills questionnaire and biochemistry questions as a pretest to respondents. Fourth, Researchers divided the respondents into 2 groups, the TGT and jigsaw groups. Then the researcher held 1-3 session meetings. For TGT student decide in 6-7 student each group. Meeting in 3 times, first meeting, facilitator explained about the subject material. Second, Student tried to doing a task. Third, Doing the game. For Jigsaw student decide in 6-7 student each group. Meeting in 3 times, first, made three expert group for carbohydrate, protein, and fats. 
Second, the expert group explained the result to origin group. Third, doing the presentation, facilitator fix everything. At the end of the meeting, the researcher distributed questionnaires as a posttest. Subjects' participation in this study were voluntary. If the subjects were not willing to, the researcher did not force them and there was no punishment if the respondents refused to participate or dropped out.

\section{Data Analysis}

The data in this study were in the form of an interval. Each statement item in the questionnaire was assessed based on the scoring guidelines according to the operational definition of a variable, and then it was added to obtain a total score which then inputted into statistic test (ttest). Normality data test was carried out before statistical tests to ensure all study data were normally distributed. In this study, the learning outcome variable was not normally distributed; therefore the test conducted was the nonparametric test of Mann-Whitney. For the variable of interpersonal relationship skill, normal distribution was obtained. Therefore, the $\mathrm{t}$ test was used. The study hypothesis was accepted if the data significance is less than $\alpha(0.05)$.

This study has obtained ethical clearance No: 1005-KEPK by Health Research Ethic Committee, Faculty of Nursing Universitas Airlangga.

\section{The characteristics of respondents}

Table 1. Frequency distribution of respondent characteristics based on sex, residency, and age.

\begin{tabular}{|c|c|c|c|c|c|}
\hline \multirow[t]{2}{*}{ No } & \multirow[t]{2}{*}{ Characteristics } & \multicolumn{2}{|c|}{$\begin{array}{c}\text { TGT Group } \\
(\mathrm{n}=94)\end{array}$} & \multicolumn{2}{|c|}{$\begin{array}{c}\text { Jigsaw Group } \\
(\mathrm{n}=81)\end{array}$} \\
\hline & & Frequency & Percentage & Frequency & Percentage \\
\hline \multirow[t]{3}{*}{1.} & Sex & & & & \\
\hline & a. Male & 14 & $14.9 \%$ & 9 & $11.1 \%$ \\
\hline & b. Female & 80 & $85.1 \%$ & 72 & $88.9 \%$ \\
\hline \multirow[t]{3}{*}{2.} & Residency & & & & \\
\hline & a. Boarding house & 31 & $33 \%$ & 14 & $17.3 \%$ \\
\hline & b. Parent's house & 63 & $67 \%$ & 67 & $82.7 \%$ \\
\hline \multirow[t]{6}{*}{3.} & Age & & & & \\
\hline & a. 18 years old & 16 & $17 \%$ & 14 & $17.3 \%$ \\
\hline & b. 19 years old & 64 & $68.1 \%$ & 55 & $67.9 \%$ \\
\hline & c. 20 years old & 11 & $11.7 \%$ & 8 & $9.9 \%$ \\
\hline & d. 21 years old & 2 & $2.1 \%$ & 4 & $4.9 \%$ \\
\hline & e. 22 years old & 1 & $1.1 \%$ & 0 & $0 \%$ \\
\hline \multirow[t]{3}{*}{4.} & Status & & & & \\
\hline & a. Single & 94 & $100 \%$ & 81 & $100 \%$ \\
\hline & b. Married & 0 & $0 \%$ & 0 & $0 \%$ \\
\hline
\end{tabular}

Normality Test

Table 2. The Results of Normality Test of Learning Outcome Data and Interpersonal Skill using Kolmogorov-Smirnov Test

\begin{tabular}{lcccr}
\hline \multicolumn{5}{c}{ Kolmogorov-Smirnov $^{\text {a }}$} \\
\hline & Statistic & df & Sig. \\
\hline Learning Outcomes & .088 & & 175 & .002 \\
\hline $\begin{array}{l}\text { Interpersonal } \\
\text { Relationship }\end{array}$ & .043 & 175 & $.200^{*}$ \\
\hline
\end{tabular}




\section{Respondents Learning Outcomes}

Table 3 Analysis of the effectiveness of the jigsaw method implementation compared to the Team Game Tournament (TGT) method on the achievement of learning outcomes

\begin{tabular}{cccccccc}
\hline \multirow{2}{*}{ No } & Group & \multicolumn{2}{c}{ Before } & \multicolumn{2}{c}{ After } & $\begin{array}{c}\text { Mean } \\
\text { rank }\end{array}$ & $\begin{array}{c}\text { Wilcoxon } \\
\text { test }\end{array}$ \\
\cline { 3 - 7 } & & $\mathrm{n}$ & Percentage & $\mathrm{n}$ & Percentage & & \\
\hline 1 & TGT & 94 & $100 \%$ & 94 & $100 \%$ & 97.89 & 0.001 \\
\hline 2 & Jigsaw & 81 & $100 \%$ & 81 & $100 \%$ & 76.52 & 0.001 \\
\hline Mann- & & & & & & \\
\hline & $\begin{array}{c}\text { Whitney } \\
\text { Test }\end{array}$ & & & 0.005 & & \\
\hline
\end{tabular}

\section{Interpersonal Relationship Skills}

Table 4 Analysis of the effectiveness of the jigsaw method implementation compared to the Team Game Tournament (TGT) method on the interpersonal relationships skills

\begin{tabular}{|c|c|c|c|c|c|c|c|}
\hline \multirow[t]{2}{*}{ No } & \multirow[t]{2}{*}{ Group } & \multicolumn{2}{|c|}{ Before } & \multicolumn{2}{|r|}{ After } & \multirow[t]{2}{*}{ Mean \pm SD } & \multirow{2}{*}{$\begin{array}{c}\text { Paired } t- \\
\text { test }\end{array}$} \\
\hline & & $\mathrm{n}$ & Percentage & $\mathrm{n}$ & Percentage & & \\
\hline 1 & TGT & 94 & $100 \%$ & 94 & $100 \%$ & $\begin{array}{c}168.82 \pm \\
16.092\end{array}$ & 0.804 \\
\hline 2 & Jigsaw & 81 & $100 \%$ & 81 & $100 \%$ & $\begin{array}{c}171.48 \pm \\
15.125\end{array}$ & 0.171 \\
\hline & $\begin{array}{c}\text { Independent } \\
\text { t-test }\end{array}$ & & & & 0.263 & & \\
\hline & $\begin{array}{c}\text { Mean } \\
\text { difference }\end{array}$ & & & & -2.662 & & \\
\hline
\end{tabular}

\section{RESULTS}

Based on the analysis results of respondents characteristics in table 1 consisted of sex, residency, age, and status, $80(85.1 \%)$ of students were female, 63 $(67 \%)$ of students were living with their parents and $64(68.1 \%)$ of students were 19 years old in the group received Team Game Tournament (TGT) intervention. Meanwhile, $72(88.9 \%)$ of students were female, $67(82.7 \%)$ of students were living with their parents, and $55(67.9 \%)$ of students were 19 years old in the group received jigsaw earning method intervention. One hundred percent of respondents from both groups were single.

Based on the table 2, learning outcomes variables scored $\alpha<0.05$ (sig
Kolmogorov Smirnov 0.002) which means it is not normally distributed, therefore the parametric tests (independent t-test) could not be conducted. Thus, a non-parametric test was conducted using the Mann Whitney test. Meanwhile, the interpersonal relationship variable scored $\alpha>0.05$ (Kolmogorov Smirnov sig 0.2) which means that the data is normally distributed and could be continued for parametric testing using t-test.

Based on table 3 (the Wilcoxon test results), $\mathrm{p}$-value $=0.001(\mathrm{p}<\alpha(0.05))$ for both learning methods applied. Thus, there were differences in learning outcomes before and after treated for learning methods in both the TGT and jigsaw groups. In addition, based on the Mann Whitney test results, the mean value of the 
jigsaw method is 76.52 which lower than the mean rank of the TGT method of 97.89 . The difference in the mean value of the rank was considered to be significant based on the Asymp. Sig. (2-tailed) score of 0.005 $<\alpha(0.05)$, which means that there were differences in learning outcomes between the TGT group and the jigsaw group after treated with the TGT and jigsaw learning methods.

Based on table 4, it was found that there was no difference in the respondents' interpersonal relationships skills either before or after the TGT and jigsaw learning methods intervention, with the $\mathrm{p}=0.804$ $(\mathrm{p}>\alpha(0.05))$ for the TGT method and $\mathrm{p}=$ $0.171(\mathrm{p}>\alpha(0.05))$ for the jigsaw method. Based on the results of the independent $t-$ test, the mean difference for interpersonal relationships is -2.662 which means that the mean score of the TGT group is 2.662 smaller than the jigsaw method group with $\mathrm{p}=0.263(\mathrm{p}>\alpha(0.05))$. This means that there is no difference between the interpersonal relationships skills of respondents intervened in the TGT and jigsaw learning methods.

\section{DISCUSSIONS}

\section{Implementation of Team Games Tournament (TGT) and the Jigsaw Learning Methods on Learning Outcomes}

Based on the study results conducted, there are differences in student learning outcomes before and after the implementation of the TGT and jigsaw learning methods in biochemistry subjects. Both methods are effective to improve student learning outcomes in biochemistry subjects. Additionally, there are also differences in learning outcomes between the groups received the TGT learning method and the jigsaw learning method ( $\mathrm{p}$ $=0.005$ ). The mean value of the jigsaw method group is 76.52 , lower than the mean TGT method rank of 97.89. Thus, the learning outcomes with the TGT learning method have a higher average score compared to the learning outcomes with the jigsaw learning method. This means that the TGT learning method is more effective in improving student learning outcomes in biochemistry subjects compared to jigsaw learning methods. This is consistent with the study conducted by Hidayati, et al, (2014) who obtained the results that the TGT method produces better learning achievement than the jigsaw and conventional in mathematics subject.

According to Shoimin (2014) cooperative learning of the TGT model is easy to implement and involves the activities of all students without any difference in status, involving the role of students as peer tutors and containing game elements and reinforcement. Learning activities with games designed in cooperative learning in the TGT model allow students to learn in a more relaxed atmosphere, in addition to fostering responsibility, collaboration, healthy competition, and learning involvement. TGT learning method begins with the delivery of the subject outline by the teacher. Then, students are divided into several groups according to their skill level. Students discuss in groups to work on questions, while the teacher provides sufficient knowledge. After the discussion, each representative from the group pick up the shuffled question cards, then each group competed to answer the questions asked. Then, the teacher concludes the learning subjects (Slavin in Solehatin and Raharjo, 2009). Meanwhile, the jigsaw learning method is a multifunctional structure of cooperation in learning. Jigsaw can be used in several ways to achieve learning goals such as for presentations and getting new subjects. The structure of a jigsaw method can create a dependency between groups. This jigsaw method can be used on all subjects and at all levels to develop the skills and mastery of each group member (Susanto, 2014).

TGT is a learning method which contains games in it, different from jigsaw that is in the form of group discussion models. This will create a fun game that can increase student motivation in learning, which leads to improved learning outcomes. According to Juwita (2017), the TGT learning method affects learning motivation and student learning outcomes. 
This is in line with research conducted by Rakhmadhani (2013) that the TGT method with game modification is more effective and can improve learning outcomes and. Likewise, the jigsaw method is also effective in improving learning outcomes. Research conducted by Sulistyaningsih et al., (2012) states that the Jigsaw method with the modification of learning CD can improve student learning achievement in mathematics learning.

The difference in learning outcomes of biochemistry subjects in the two groups of respondents can occur because of the weakness in the jigsaw learning method. According to Kusharyati (2009), this jigsaw learning method requires longer time and more skills from the facilitator to pay the attention to groups because of the different needs of each group. Likewise, according to (Sabil, 2013) the weakness of the jigsaw method is a short time and the facilitator's skills in facilitating the learning process or discussion which requires them to master the subjects and class. This problem was also found in the study process where the jigsaw learning method intervention was performed in 3 meetings and each meeting was 100 minutes long. There is lack of available time in the learning process in the jigsaw method, which makes the discussion process or the transfer of knowledge from the expert group to the origin group is not optimal. This lack of time in the process of transfer of knowledge can be the reason of lower students learning outcomes in the jigsaw group than students in the TGT group.

The research conducted by Agus Hariyanto (2016) shows that the TGT model with a scientific approach had significant changes to the cognitive learning outcomes compared to the jigsaw model with a scientific approach. In cognitive theory, the freedom and active involvement of students in the learning process are necessary. Student learning which is guided by adults or peers will ease the understanding by discussing and playing in an active learning process in groups create a pleasant atmosphere and away from boredom and tension. Thus, the difficult to understand subjects will be easier to be absorbed and boredom can be overcome. The same thing is also obtained from the research results conducted by Mirati (2015), which stated that the TGT learning method is more effective in learning achievement in mathematics compared to the jigsaw method. According to Mirati (2015) this happens because all students are active in playing games or tournaments. Through the games and tournaments, students are more familiar with the sample questions. Meanwhile in jigsaw learning, the expert groups look active during the discussion, but the students have difficulty transferring the knowledge they obtained in the expert group to their original group. This is similar to the observations results conducted by researchers, where when the TGT learning method was applied all students were active in the process. The students were more relaxed because of the game in the learning process. Unlike the jigsaw method where the learning model is performed by discussion without playing games, students seem to be tenser and feel less confident when discussing back to the original group. Students who were lack of skills were likely to be reluctant to engage in group discussions. This caused the transfer of knowledge to be less effective so that learning outcomes are less effective than the TGT learning method.

\section{Implementation of Team Games Tournament (TGT) Learning Method and Jigsaw Method on the Interpersonal Relations Skills}

Based on the study results conducted, it was found that there is no difference between the interpersonal relationship skills between students before and after TGT and jigsaw learning methods intervention. The comparison of the interpersonal relationship skills of students in TGT and the jigsaw learning method was $(\mathrm{p}=0.263)$, which means that there is no difference in the students' interpersonal relationships skills in the TGT and jigsaw learning methods group. Based on the observations results condu thected, this is because students were in the group before. The group division is based on the daily class of the respondent. 
Thus, the students' interpersonal relationships skills have been formed beforehand. Therefore, TGT and jigsaw learning methods intervention do not affect the students' interpersonal relationships skills. Additionally, based on the study results of the mean score of students' interpersonal relationship skill was 168 for TGT and 171 for jigsaw method. Both scores are categorized as good. Thus any learning method will not affect the change in the students' interpersonal relationships skills because it is in a good category.

According to Spitzberg and Cupach (in Idrus, 2009), interpersonal relationships skill is the ability in effective communication, with certain psychological characteristics to produce good and satisfying relationships between individuals. If the relationship in question has been achieved, then it will be easier for the individual to achieve the goal. According to Idrus (2009), students' interpersonal relationships skill is influenced by peer interaction. With peers, one's fantasy can be developed, many roles are tried, social competencies are developed, and trying to understand social rules, culture, and norms in the environment. Peer relationships are not unidirectional relationships but there are two-way interactions of give-and-take. This can develop better interpersonal skills. In accordance with the results of the study, the mean score of students' interpersonal relationship skills were 168 for TGT and 171 for jigsaw method. Both scores are categorized as good. The respondents in this study were all peers with the majority of respondents are 19 years old. Thus the interpersonal relationships skill has been formed before in the classroom.

TGT and jigsaw learning methods are two methods of cooperative learning, where students are divided into groups. Learning in groups with TGT and jigsaw learning methods makes students understand the subjects easier through discussion and playing with friends in groups. The activities include asking more competent friends so that they can help each other. The active activities in groups help to create a more relaxed atmosphere. A comfortable learning atmosphere creates more active interactions in groups (Agus Hariyanto et al., 2016). Through these activities, students' interpersonal relationships skill that was initially in a good category will remain good. Other group learning methods can also affect students' interpersonal relationship skills.

\section{CONCLUSIONS}

There are differences in the effectiveness of the implementation of team game tournament learning methods compared to jigsaw learning methods on learning outcomes in biochemistry subjects. TGT learning method is more effective than the jigsaw method. TGT can increase student learning outcomes higher than jigsaw. But there is no difference in the effectiveness of interpersonal relationship skills in these two methods in biochemistry subjects. The student has been in good criteria of interpersonal relationship skill.

The suggestion given is for nursing education institutions to apply cooperative learning methods and develop methods and modify them for other learning subjects especially for nursing courses.

\section{REFERENCES}

Alsa, A. (2010) 'Pengaruh Metode Belajar Jigsaw Terhadap Keterampilan Hubungan Interpersonal dan Kerjasama Kelompok pada Mahasiswa Fakultas Psikologi', Jurnal Psikologi, 37(2), pp. 165-175.

Aronson, E. (2009). Jigsaw classroom. Social Psychology network. http://www.jigsaw.org/steps, diakses tanggal 10 April 2018

Anwar, Y, Junaidi, E, Idrus, S. (2014). Analisis Kesullitan Belajar Mahasiswa Dalam Upaya Pengembangan Perangkat Pembelajaran Berbasis Daur Belajar Johnston. Jurnal Kajian Peenelitian dan Pengebangan Kependidikan Paedagoria, 5(1).

Dimyati dan Mudjiono. (2006). Belajar dan Pembelajaran. Jakarta: PT Rineka Cipta. 
Hamdani, (2011).Strategi Belajar mengajar. Bandung: CV Pustaka setia.

Hariyanto, A., Zuchdi, D. (2016). Keefektifan Model Tgt Dan Jigsaw Dengan Pendekatan Saintifik Pembelajaran Ekonomi Sma Negeri Di Sleman. Harmoni Sosial, 3(2), 125-137.

Hidayati, N., Mardiyana, \& Riyadi. (2014). Eksperimentasi Pembelajaran Matematika dengan Model Pembelajaran Kooperatif Jigsaw dan Teams Games Tournament (TGT) Ditinjau dari Kecerdasan Intrapersonal Siswa. Elektronik Pembelajaran Matematika, 2(2), 152162. Retrieved from http://www.jurnal.fkip.uns.ac.id/index .php/s2math/article/view/3913

Idrus, M. (2009). Kompetensi interpersonal mahasiswa. Unisia, 32(72), 171-184.

Juwita, L, Sari, N. P, Septianingrum, Y. (2017). Pengaruh Penerapan Metode Pembelajaran Kooperatif Team Game Tournament (TGT) Terhadap Motivasi Belajar Dan Hasil Belajar Mahasiswa Keperawatan Dalam Materi Anatomi Fisiologi Sistem Saraf. Laporan Penelitian AINEC research award.

Mirati, L., Riyadi, \& Sujadi, I. (2015). Efektifitas Model Pembelajaran Kooperatif Jigsaw Ii Dan TeamsGames-Tournaments ( Tgt ) Pada Materi Barisan Dan Deret Ditinjau Dari Tipe Kepribadian Siswa Smk Kelas X. Jurnal Elektronik Pembelajaran Matematika, 3(5), 518528.

Raksun, A. (2008). Motivasi Dan Hasil Belajar Mahasiswa Program Studi Pendidikan Fisika Fkip Universitas Mataram Pada Matakuliah Biologi Dasar. Jurnal Pijar MIPA, Vol III(1), 6-10.
Sabil, H. (2013). Meningkatkan Hasil Belajar Matematika Siswa Melalui Pembelajaran Aktif Model Jigsaw pada materi Himpunan di Kelas VII SMPN 7 Muaro Jambi. Jurnal Pendidikan Matematika, 03(02), 5357.

Shoimin, Aris. (2014). 68 Model Pembelajaran Inovatif Dalam Kurikulum 2013. Yogyakarta: ArRuzz Media

Slavin, R.E. (2009). Educational psychology. Englewoods Cliffs, New Jersey: Prentice Hall International Limited.

Sugihartono, dkk. (2007). Psikologi Pendidikan. Yogyakarta: UNY Press

Sulistyaningsih, D., Joko, I., Studi, P., Matematika, P., Keguruan, F., \& Pendidikan, I. (2012). Meningkatkan Hasil Belajar Matematika Siswa Melalui Metode Pembelajaran Jigsaw Berbantuan Cd Pembelajaran Materi Ekponen Kelas X. Jurnal Unimus. Retrieved from http://download.portalgaruda.org

Susanto, Ahmad. (2014). Pengembangan Pembelajaran IPS di Sekolah Dasar. Jakarta: Prenadamedia Group

Veloo, A., \& Chairhany, S. (2013). Fostering Students' Attitudes and Achievement in Probability Using Teams-games-tournaments. Procedia - Social and Behavioral Sciences, 93, 59-64.

https://doi.org/10.1016/j.sbspro.2013. 09.152

Yusup. (2014). Hubungan Interpersonal Antar Siswa dan Keaktifan Belajar dengan Prestasi Belajar Siswa Program Keahlian Teknik Bangunan SMK Negeri 3 Yogyakarta. Skripsi Fakultas Teknik Universitas Negeri Yogyakarta. 